\title{
Oral and dental management in children with tetralogy of fallot
}

\author{
Arlette Suzy Puspa Pertiwi, Inne Suherna Sasmita and Yetty Herdiati Nonong \\ Department of Pediatric Dentistry \\ Faculty of Dentistry, Padjadjaran University \\ Bandung - Indonesia
}

\begin{abstract}
Tetralogy of fallot is one of the congenital cyanotic heart disease that is often found in children. The disorder has four features, a ventricular septal defect, aortic overriding, infundibulary stenotic, and hypertrophy right ventricular. Like other congenital heart disease, tetralogy of fallot sometimes related to fatal complications, such as bacterial endocarditis which was related to dental infections. The correct management of oral and dental conditions is important to prevent bacterial endocarditis. This paper discussed the oral and dental conditions and its management in two cases of tetralogy of fallot children.
\end{abstract}

Key words: Oral and dental condition, Antibiotic, Cyanotic heart disease

Correspondence: Arlétte Suzy Puspa Pertiwi, c/o: Bagian Kedokteran Gigi Anak, Fakultas Kedokteran Gigi Universitas Padjadjaran. Jl. Sekeloa Selatan I Bandung 40132 Indonesia. E-mail: arlettesuzy@ yahoo.com, Telp/Fax. 0222533031.

\section{INTRODUCTION}

Tetralogy of fallot (ToF) is a congenital cyanotic heart disease that is often found in children, approximately around of $7-10 \%$ from overall congenital heart disease in children. The disorder includes ventricular septal defect, aortic overriding, infundibullary stenotic, and hypertrophy right ventricular. ${ }^{1}$ Defects of ToF describe as a hole in the wall between the ventricles (ventricular septal defect) which lets oxygen-poor blood mix with oxygen-rich blood. An obstruction from ventricle to the lungs (pulmonal stenotic) is an important feature cause by the blockade of blood flow from the right ventricle into the lungs due to a narrowed outlet to the pulmonary artery, usually along with an abnormal pulmonary valve. Be aside of all, an aorta that straddles the septum (overriding) between the ventricles will lets oxygen-poor blood flow into the aorta and also due to a thickened and enlarged heart muscle tissue in the right ventricle. ${ }^{2}$

Overriding aorta above the ventricular defect and pulmonal stenotic allows the blood from the ventricles to be pump into the body. Together, these defects make the level of oxygen in the blood low. These allow a bluish appearance (cyanotic) when oxygen-poor blood is pumped into the body, the fingers, toes, and lip. ${ }^{2}$ Child with ToF may feel easily exhausted, short winded, and hyperpnoea caused by hypoxia. Sometimes the cyanotic does not clearly appear. Tip of fingers and toes showed a clubbing shape and cyanotic. Patient often do a squatting position after a certain distance walk or even cry. This position is necessary to enhance periphery resistance and restrain the blood flow from the extremities into the heart. ${ }^{1}$ Further on, the increase of systemic resistance from a squatting position may repair the lungs oxygenation. ${ }^{3-5}$
Like any other cyanotic congenital heart disease, in ToF sometimes lead to a fatal complication such as bacterial endocarditis. Incidence of bacterial endocarditis in ToF is $15 \% .{ }^{1}$ Bacterial endocarditis is caused by a bacterial infection in heart valve or endocardium. In the field of dentistry, bacterial endocarditis is closely related to dental infection. Poor dental condition mostly found in a child with ToF is due to a disturbance in enamel development. Gingival hypertrophy may be present and the tongue shows a map appearance of geographic tongue. ${ }^{2}$ Dentist's role is highly needed in an attempt to prevent this complication. ${ }^{5}$

Invasive dental treatment, such as extraction, scaling, oral surgery, and endodontic treatment may cause bacteriemia. ${ }^{6}$ Dental procedures that allow trauma in soft tissue or bone may lead to a bleeding which can cause transient bacteriemia. The condition in a certain patient may cause endocarditis. Minor dental treatment, such as placing matrix band may lead to transient bacteriemia which further lead to bacterial endocarditis. ${ }^{5,6}$ The attempt to prevent bacterial endocarditis is the administration of prophylactic antibiotic. Oral Streptococcus such as S. sanguis and S. mitis are the organism which mostly cause bacterial endocarditis. ${ }^{6}$

Children with ToF are in a high risk of caries, especially in primary dentition. These are due to a certain medication for heart disease contains a high concentrate of sugar and further on, there is an increase in the prevalence of enamel mineralization disturbance. Preventive efforts include the dietary counseling, fluoride administration, pit and fissure sealant, and oral hygiene instruction. ${ }^{6,7}$ These clinical reports discuss two cases of dental management in children with ToF. 


\section{CASES}

First case: R, nine year old boy was referred to Special Dental Care clinic in Hasan Sadikin Hospital from his pediatric cardiologist to search for focal infection prior heart surgery. Patient was diagnosed as ToF since the age of eight, but the clinical signs such as fatigue, short winded, and often make a squatting position was already exist since toddler. At the moment, the patient is unable to walk and have to be carried by his parents.

Diagnoses from the pediatric cardiologist were diagnosis of function (DF): compensated heart disease, diagnosis of anatomy (DA): ToF, and diagnosis of etiology (DE): congenital heart disease cyanotic type. Physical examination showed a delayed growth and development compare to a normal child at his age. Patient looked fatigue and bluish. Fingers and toes showed clubbing shape (Figure 1). Intra oral examination showed cyanotic in lip, buccal, and gingival mucosa. Diagnosis of necrotic pulp in teeth no 75,
$74,84,85,64,65$ and pulp hyperemia in teeth no 54, 53, 62,63 . Oral hygiene was in mild condition.

Second case: Rz, four year-old boy also referred to Special Dental Care clinic by his pediatric cardiologist to search for focal infection and it's management prior to heart surgery. Patient showed the sign of heart disease since the age of 5 months. Diagnosis from pediatric cardiologist is diagnosis of function (DF): compensated heart disease, diagnosis of anatomy (DA): variant $\mathrm{ToF}+$ bacterial endocarditis, and diagnosis of etiology (DE): congenital heart disease cyanotic type. Physical examination showed failure to thrive. Patient was unable to walk. Skin was pale and bluish with clubbing fingers and toes (Figure 3).

Intra oral examination showed poor oral hygiene and generally chronic marginal gingivitis. Lips, tongue, gingival and buccal mucosa were cyanotic. Dentine caries at teeth no $55,53,63,65,73,72,71,81,82,83$. Caries that reach the pulp in teeth no $54,64,75,74,84$. Radix in teeth no $52,51,61,62$.
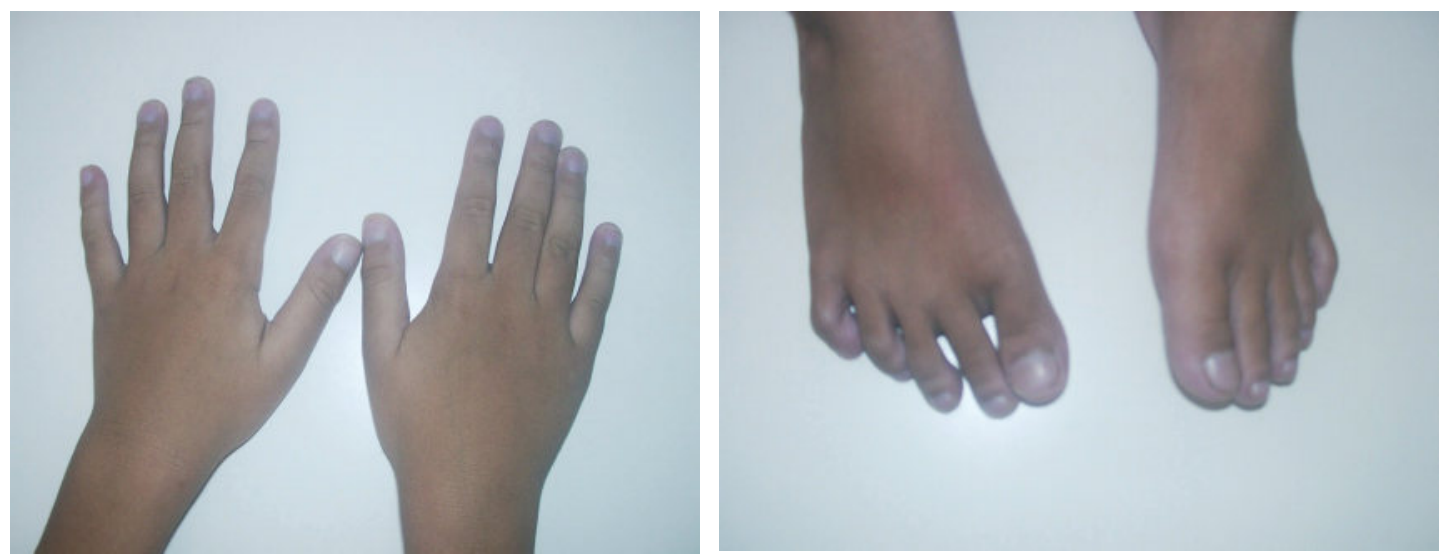

Figure 1. Clubbing and cyanotic fingers and toes.
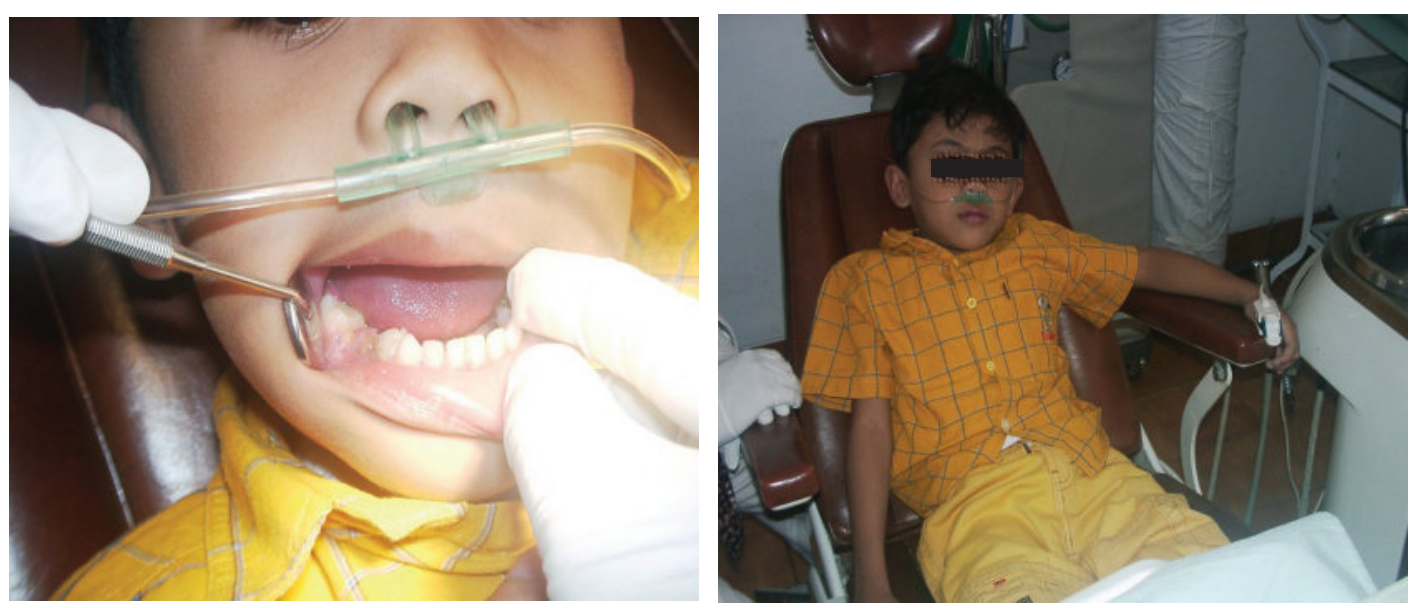

Figure 2. Patient was monitored by pulse oxymetry and administred oxygen inhalation. 

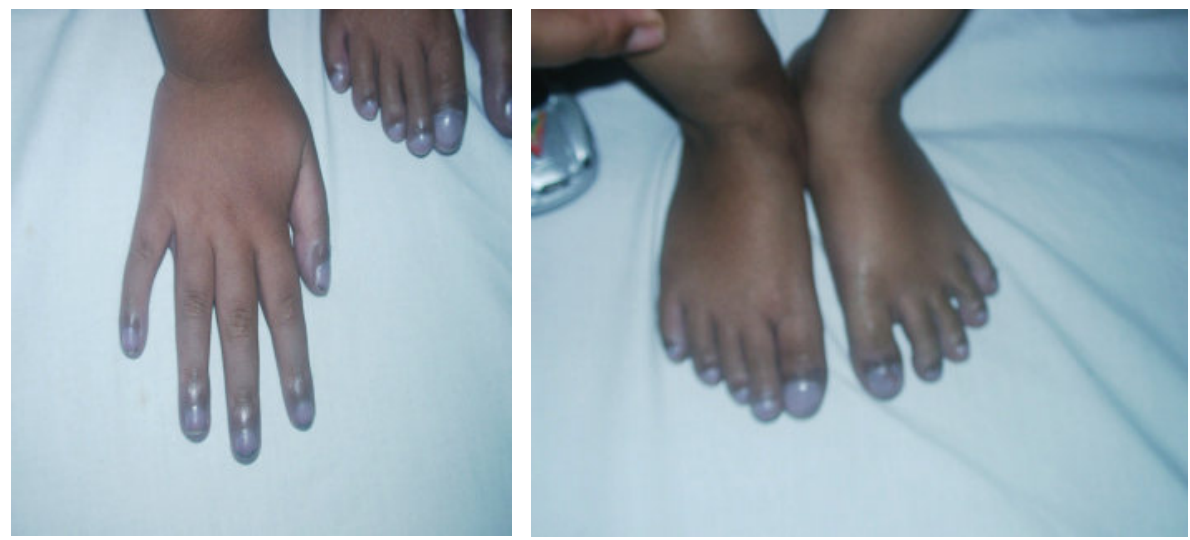

Figure 3. Clubbing and cyanotic fingers and toes.

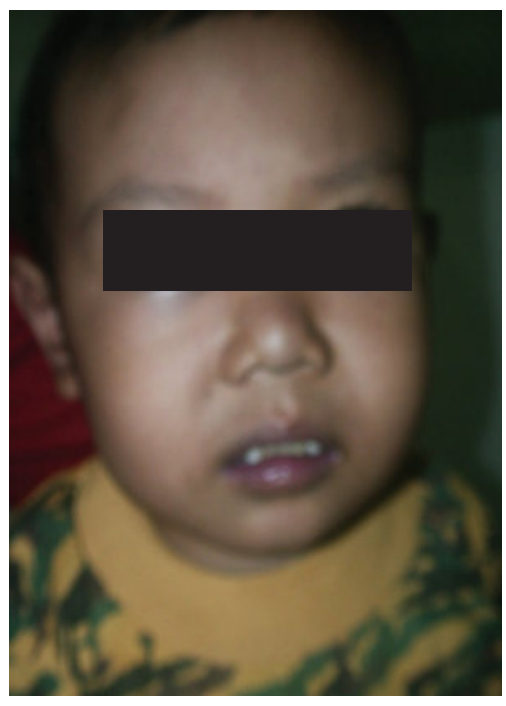

Figure 4. Patient's profile.

\section{CASES MANAGEMENT}

Dental treatments for the first case consist of preventive and curative efforts. Preventive treatments were carried out by oral hygiene instruction and topical fluoride application. Curative treatments are extraction of the teeth with necrotic pulp and glass ionomer cement fillings in hyperemia pulp teeth. To prevent bacterial endocarditis, patient was given a prophylactic antibiotic $50 \mathrm{mg} / \mathrm{kg}$ body weight one hour prior before treatment. During the dental procedure, patient was monitored by pulse oximetry to monitor the oxygen saturation and heart pulse. Patient was also inhale oxygen (Figure 2). Patient was very cooperative, so the dental treatment was done after two months periods.

As for the second case, dental management was different than the first case. Patient was extremely uncooperative. Treatment plan were extraction of teeth no 52, 51, 61, 62, $54,64,75,74,84$ and filling in teeth no 55, 53, 63, 65, 73, 72, 71, 81, 82, 83. Antibiotic prophylactic (Amoxicillin) was considered to be given $50 \mathrm{mg} / \mathrm{kg}$ body weight 1 hour before the procedure.

In the first visit, patient was very uncooperative, he revolted and cried so the oxygen saturation drop to 10 percent (normally, he have oxygen saturation of 60-70 percent, normal child should have the value of 100 percent). Considering the dental treatment will harm the patient, so he was scheduled to the dental treatment under general anesthesia. Laboratory and radiographic examination were carried out and the case was discussed in a join conference with pediatricians and anesthesiologist. Thorax photo showed an enlarged heart of increase vascular marking, no sign of active specific process, and an opaque round shadow in the right par tracheal.

The join conference concluded that the dental treatment under general anesthesia can not be carried out at Hasan Sadikin Hospital because this patient is in a high risk due to a severe condition of ToF. Patient was referred to undergo mouth preparation under general anesthesia at Harapan Kita Hospital.

\section{DISCUSSION}

Oral and dental treatment in a child with congenital heart disease is very important. Main point which have to be noticed is that patient with this disorder is highly susceptible 
to bacterial endocarditis. In the first case, the history of bacterial endocarditis was not yet exists. But in the second case, the bacterial endocarditis was already exists. This was due to poor oral hygiene in the second patient.

Every dental procedures which may lead to a damaged of soft tissue can cause transient bacteriemia and thus in a certain condition cause to bacterial endocarditis. ${ }^{5}$ Transient bacteriemia may exists after physiological activities which involves the mouth, such as mastication and tooth brushing. According to Guntheroth, transient bacteriemia that happens after physiological activities is 1000 fold higher than after dental procedures. However, the risk of bacteriemia in a patient with a clean and healthy oral cavity is lower than patient with poor oral hygiene. 5

Bacterial endocarditis that caused from oral bacteria has to be prevented with the administration of prophylactic antibiotic. Antibiotic can prevent endocarditis by killing the bacteria or damage it so it can be destroyed by host defense. The effect may occur in oral cavity, blood flow, or after the organism adherence in the heart. ${ }^{5}$ Both cases was administered prophylactic antibiotic (Amoxicillin) in a dose of $50 \mathrm{mg} / \mathrm{kg}$ body weight 1 hour prior to each visit. The important point to be remembered in the administration of prophylactic antibiotic is to be carried out at every treatment in every visit, considering patient's emotional state. ${ }^{6}$ In every visit, the first patient was extracted 1-2 teeth depend on the patient's state of health.

Beside prophylactic antibiotic, the risk of developing bacterial endocarditis can be minimized by preventive dental procedure. These contain of routine dental check up, fluoridation, dietary modification to minimize the risk of dental caries and periodontal disease, and day care maintenance of oral hygiene (tooth brushing), ${ }^{5,9,10}$ Topical fluoride application in the first case is aimed as preventive treatment while curative treatment is in the form of extraction of a tooth with pulp involved caries and filling in dentine caries diagnosed tooth. In a normal patient, pulp involved tooth can be treated with pulp therapy, but in patient with ToF can not be carried out due to the risk of bacterial endocarditis. ${ }^{11}$

Patient in the first case is very cooperative, thus the dental treatment can be carried out through psychological approach. During the procedure, patient's status was monitored by pulse oximetry. Oxygen saturation of this patient was below 70 percent, thus patient was administered oxygen inhalation during the treatment. The patient have the risk of respiratory arrest due to disorders in pulmonary value. ${ }^{12,13,14}$ In the second case, conventional dental treatment can not be carried out due to patient uncooperativeness. Patient was scheduled to undergo mouth preparation under general anesthesia, but considering that this patient has severe ToF, the procedure can not be carried out in Hasan Sadikin Hospital.

Oral and dental treatment is important to be carried out in children with the risk of bacterial endocarditis. Patient in a good general condition can receive every dental treatment as long as covered by prophylactic antibiotic. The important aspects of dental treatment are dental health education, preventive dental treatment, and maintenance after dental treatment. Dental health education can be delivered since the child showed heart disorder considering congenital heart disease mostly showed the clinical signs in infancy. Early dental health education can minimize oral and dental disease which may risk the existence of bacterial endocarditis.

\section{REFERENCES}

1. Baraas F. Penyakit jantung pada anak. Jakarta: Balai Penerbit Fakultas Kedokteran Universitas Indonesia; 1995. p. 140-51.

2. Tetralogy of fallot. Texas: Texas Heart Institute. Available from URL: www.americanheart.org Accessed Nopember 28, 2005.

3. Markum AH. Buku ajar ilmu kesehatan anak. Jilid 1. Jakarta: Balai Penerbit Fakultas Kedokteran Universitas Indonesia; 1991. p. $577-81$.

4. Gordon IB. Sistem kardiovaskuler. In: Behrman RE, Voughan VC, Nelson, editors. Ilmu kesehatan anak. Bagian 2. Jakarta: EGC; 1992. p. 726-34.

5. Sinaga LE, Wahab AS. Kardiologi anak tetralogi fallot. Yogyakarta: Bagian Ilmu Kesehatan Anak, Fakultas Kedokteran Universitas Gadjah Mada; 2004. p. 26.

6. Little JW, Falace DA. Dental management of the medically compromised patient. $6^{\text {th }}$ ed. St Louis: Mosby Inc; 2002. p. 21-63.

7. Koch G, Poulsen S. Pediatric dentistry, a clinical approach. Copenhagen: Munksgaard; 2001. p. 428.

8. Cameron AC, Widmer RP. Handbook of pediatric dentistry. $2^{\text {nd }}$ ed. Sydney: Mosby Inc; 2003. p. 234-6.

9. Welburry RR. Pediatric dentistry. $2^{\text {nd }}$ ed. New York: Oxford University Press; 2001. p. 374-8.

10. McCallum CA. Oral surgery for children. In: Finn SB, editor. Clinical pedodontics. $4^{\text {th }}$ ed. Philadelphia: WB Saunders Co; 1991. p. 392, 438, 581-2.

11. Mathewson RJ. Fundamentals of pediatric dentistry. $3^{\text {rd }}$ ed. Chicago: Quintessence Books; 1995. p. 89-104.

12. Van der Wall EE, Mulder JM. Pulmonary valve in patient with tetralogy of fallot. European Heart Journal 2006; 26(24):2624-5.

13. Saygih A, Aytekin C, Boyvat F, Barutçu Ö, Mercan Ş, Tokel K. Endobronchial stenting in a two-,onth-old infant with bronchial compression secondary to tetralogy of fallot and absentpulmonary valve. The Turkish Journal of Pediatric 2004; 46(3):268-71.

14. Rowland DG, Caserta T, Foy P, Wheller J, Allen H. Congenital absence of the pulmonary valve with stenosis and patent ductus arteriosus: a prenatal diagnosis. American Heart Journal 1996; 132(5):1075-7. 